\title{
Detection of Leguminous Protein in Casein by Nitrogen Stable Isotopes
}

\author{
Joachim Molkentin ${ }^{1}$ \\ ${ }^{1}$ Department of Safety and Quality of Milk and Fish Products, Max Rubner-Institute, Kiel, Germany \\ Correspondence: Joachim Molkentin, Department of Safety and Quality of Milk and Fish Products, Max \\ Rubner-Institute, Hermann-Weigmann-Str. 1, 24103 Kiel, Germany. E-mail: joachim.molkentin@ mri.bund.de
}

Received: January 27, 2018

Accepted: February 21, 2018 Online Published: March 16, 2018

doi:10.5539/jfr.v7n3p1

URL: https://doi.org/10.5539/jfr.v7n3p1

\begin{abstract}
Casein can legally be substituted with cheaper leguminous proteins in processed foods, such as imitation cheese, as long as the ingredients are declared. The detection of illegal admixtures of leguminous protein requires analytical procedures to identify an undisclosed adulteration of milk products. To investigate the suitability of stable isotope analyses as an alternative to more sophisticated methods, variations in $\delta^{15} \mathrm{~N}$ of soya $(\mathrm{n}=27)$ and peanut $(\mathrm{n}=10)$ protein, as well as casein $(\mathrm{n}=14)$ were determined. Significant differences were established between $\delta^{15} \mathrm{~N}$ of casein $(4.45-6.94 \%)$ and soya $(0.25-2.37 \%)$ as well as peanut $(0.70-2.13 \%)$ protein. An average limit of detection for leguminous protein in casein was determined to be $2.1 \%$, provided both components were available for additional analyses. Under practical conditions of food control, i.e., without having access to the actual ingredients, the variability of $\delta^{15} \mathrm{~N}$ resulted in an average limit of detection of 26.4\%. Because protein $\delta^{15} \mathrm{~N}$ can be determined rapidly in crude food samples without elaborate sample preparation, stable isotope analysis can be used as a rapid screening method to determine the presence of higher amounts of leguminous protein in cheese and, in particular, to easily distinguish imitation cheese from cheese.
\end{abstract}

Keywords: casein, soya, peanut, protein, cheese, adulteration, stable isotopes, nitrogen

\section{Introduction}

Wide areas of food production are dominated by economic forces towards the aim of optimizing profits. Hence, the substitution of ingredients with cheaper components or the use of surrogates can be a logical consequence. In particular, processed food items such as baked goods, pizza or other instant meals have frequently been shown to contain imitation cheese. The milk fat and/or casein in imitation cheese are replaced by vegetable fats or proteins. A common substitute for milk fat is palm oil, whereas casein can be replaced by soya or peanut protein.

It is entirely legal to sell products that contain imitation cheese, as long as they are not declared as cheese products. According to EU regulation 1234/2007 (EU, 2007), cheese is a product that is made exclusively from milk, with the exception of agents required for production, and a product in which the dairy ingredients have been neither fully nor partially replaced. Consequently, imitation cheese products marketed under the term "cheese" must be rejected, which requires suitable detection methods in food control.

The partial or fully absence of milk fat in a disputed product can easily be recognized by determining the content of butyric acid in the lipid fraction by gas chromatography (Molkentin \& Precht, 1998). Butyric acid is found only in milk fat and not in any vegetable or animal body fats, so reduced butyric acid contents or its absence indicate the presence of non-milk fats. Furthermore, foreign fats can be detected using gas chromatography of triglycerides (IDF, 2010), which is a more sensitive method of detection than butyric acid analysis.

The addition of non-dairy protein to milk products classically can be detected using polyacrylamide gel electrophoresis (PAGE) (Hewedy \& Smith, 1989) or capillary electrophoresis (Kanning, Casella, \& Olieman, 1993). The detection limit for soya protein in cheese can be lowered to $0.06 \%$ of the total protein content by using SDS-PAGE (Cattaneo, Feroldi, Toppino, \& Olieman, 1994). Moreover, biosensor immunoassays have been applied to simultaneously detect different plant proteins in milk powder below $0.1 \%$ of total protein (Haasnoot, Olieman, Cazemier, \& Verheijen, 2001). Furthermore, high performance liquid chromatography (HPLC) / mass spectrometry has been used to identify plant proteins below $1 \%$ of total protein in skimmed milk powder (Luykx et al., 2007). More recently, non-targeted screening methods were developed, utilising 
LC-Q-TOF mass spectrometry (Cordewener et al., 2009), Ultra HPLC with UV-absorbance detection (Jablonski, Moore, \& Harnly, 2014) or fourier-transform infrared spectroscopy (FTIR) (Scholl, Farris, \& Mossoba, 2014), that can detect plant proteins in milk at a $1 \%$ level. Soya specific, rapid methods comprise ATR-FTIR (Jaiswal et al., 2015) or 2D microchip capillary electrophoresis (Wu, Wang, Fung, Seah, \& Yeung, 2014), showing detection limits of $2 \%$ and $0.1 \%$ of milk protein.

The aim of the present study was to investigate the applicability of stable isotope analysis as a rapid screening method to determine the presence of certain plant proteins in milk products, especially cheese. Several agricultural plants, which are used as cheap protein sources, belong to the legume family (Leguminosae) and are capable of fixing atmospheric nitrogen by symbiotic bacteria. Hence, their protein has a stable nitrogen isotope ratio $\left(\delta^{15} \mathrm{~N}\right)$ near to air. Because animal protein (Minagawa \& Wada, 1984) and milk protein (Molkentin \& Giesemann, 2010) are known to exhibit elevated $\delta^{15} \mathrm{~N}$ values relative to atmospheric nitrogen $\left(\delta^{15} \mathrm{~N}=0 \%\right.$ ), it can be assumed that higher percentages of legume protein mixed with casein may be detected by isotope ratio mass spectrometry (IRMS), which is increasingly well-established in food control.

This study investigated the suitability and sensitivity of IRMS for determining the authenticity of cheese by focussing on nitrogen isotopes and its variation in proteins of different origin. Because the fraudulent addition of non-milk proteins to dairy products is lucrative only in higher amounts, the detection limit of a respective method need not be as low as those in the procedures described above, as long as there are no health-related concerns.

\section{Materials and Methods}

\subsection{Samples}

A range of 27 tofu products (bean curd, made from soya) was purchased between December 2012 and May 2013 from retail stores in Kiel, Germany. Moreover, 10 samples of unpeeled roasted peanuts (between December 2012 and May 2014) and 14 cream, semi-hard and hard cow milk cheeses (July 2013 and July 2015) were purchased from the same sources.

Defatted dry matter (DDM) was prepared from $12.5 \mathrm{~g}$ of tofu or $2.5 \mathrm{~g}$ of ground peeled peanuts mixed with 10 $\mathrm{mL}$ of water by removing the lipids using cyclohexane and 2-propanol (Molkentin, Lehmann, Ostermeyer, \& Rehbein, 2015). The extracted lipids were discarded and the combined sediment and aqueous layer were lyophilized to obtain DDM. In addition to protein, the DDM also contained varying amounts of carbohydrates. With respect to stable isotope analyses of protein, $\delta^{15} \mathrm{~N}$ is not inherently affected by residual carbohydrates.

Casein was obtained from lyophilized cheese samples using a mixture of petroleum ether/diethyl ether (2:1) for the extraction of lipids (Camin et al., 2015).

Protein mixtures were prepared by adding aliquots of soya protein (DDM) to casein in increments of $10 \%$ to obtain samples containing between 10 and $90 \%$ soya protein (mass fraction) of total protein. Before isotopic analysis mixtures were homogenised thoroughly.

\subsection{Stable Isotopes}

\subsubsection{Sample Preparation}

Depending on the signal amplitude, on average $900 \mu \mathrm{g}$ of DDM, casein and blends thereof, respectively, were combusted in tin capsules using a Flash EA 1112 elemental analyser (Thermo Scientific, Waltham, MA) as described previously (Molkentin \& Giesemann, 2007). The reaction gases were separated online and directly subjected to MS analysis.

\subsubsection{Stable Isotope Analyses and Calibration}

Samples were simultaneously analysed for nitrogen and carbon stable isotope contents using a Deltaplus XL isotope-ratio mass spectrometer with Isodat 2.0 software (Thermo Scientific). The isotope ratios of ${ }^{15} \mathrm{~N} /{ }^{14} \mathrm{~N}$ were expressed in \%o on a $\delta$-scale as follows (the ${ }^{13} \mathrm{C} /{ }^{12} \mathrm{C}$ ratios were expressed using a corresponding equation):

$$
\delta^{15} \mathrm{~N}[\%]=\left[\left(\mathrm{R}_{\text {sample }} / \mathrm{R}_{\text {standard }}\right)-1\right] \times 1000 ; \quad \mathrm{R}={ }^{15} \mathrm{~N} /{ }^{14} \mathrm{~N}
$$

The calculated $\delta$-values referred to the international AIR standard for nitrogen and the VPDB standard for carbon. To calibrate the urea and sucrose (Merck, Darmstadt, Germany) laboratory working standards, the following international secondary standards were used: IAEA-N1 $\left(\delta^{15} \mathrm{~N}_{\text {Air }}=0.4 \%\right)$ and IAEA-N2 $\left(\delta^{15} \mathrm{~N}_{\text {Air }}=20.3 \%\right.$ ) for nitrogen and NBS $22\left(\delta^{13} \mathrm{C}_{\mathrm{VPDB}}=-30.031 \%\right)$, IAEA-CH-3 $\left(\delta^{13} \mathrm{C}_{\mathrm{VPDB}}=-24.724 \%\right)$, and IAEA-CH-6 $\left(\delta^{13} \mathrm{C}_{\mathrm{VPDB}}=\right.$ $-10.449 \%$ ) for carbon. The working standards were analysed regularly during each sequence to monitor the repeatability of the measurements and to calibrate the nitrogen and carbon dioxide reference gases (Air Liquide, 
Düsseldorf, Germany). Repeated reference gas analyses $(\mathrm{n}=9)$ showed a standard deviation $\leqslant 0.05 \%$ for both nitrogen and carbon. To compensate for any inhomogeneity samples were analysed in triplicate and the results expressed as the mean. The standard deviation of the triplicates was always $\leqslant 0.10 \%$, with a median value of $0.03 \%$ for both $\delta^{15} \mathrm{~N}$ and $\delta^{13} \mathrm{C}$.

\section{Results and Discussion}

A validated procedure for stable isotope analysis in cheese is based on the preliminary isolation of the protein fraction, i.e. of casein (Camin et al., 2015). Thus, the present study focussed on the analysis of casein, leguminous protein or mixtures thereof. To investigate the suitability of IRMS for authenticating casein in cheese, variations of $\delta^{13} \mathrm{C}$ and $\delta^{15} \mathrm{~N}$ in cheese protein were determined and compared with the ranges that were found in soya and peanut protein. Because the $\delta^{13} \mathrm{C}$ variation ranges for peanut protein $(-25.57--23.47 \%$ o $)$ and soya protein $\left(-26.41--24.14 \%\right.$ ) completely overlapped with that of casein $(-27.10--21.98 \%), \delta^{13} \mathrm{C}$ cannot be utilized to detect admixtures of leguminous protein in milk products. It is rather unlikely that differentiation was impaired by residual carbohydrates present in leguminous DDM, because $\delta^{13} \mathrm{C}$ of carbohydrates and proteins are closely related in plants (White \& Winters, 1989). Although $\delta^{13} \mathrm{C}$ in casein of conventionally produced milk usually lies above $-23.5 \%$ (Molkentin \& Giesemann, 2010), which was also confirmed in this study, the $\delta^{13} \mathrm{C}$ ranges of soya and peanut protein were too close to adequately detect an adulteration of cheese even in products of that kind.

However, $\delta^{15} \mathrm{~N}$ values in peanut $(0.70-2.13 \%)$ and soya protein $(0.25-2.37 \%$ o were substantially lower than values obtained for casein $(4.45-6.94 \%$ ) (Figure 1), which is caused by the fixation of atmospheric nitrogen in these legumes (DeNiro \& Epstein, 1981). The ranges showed no overlap with a gap of ca. $2 \%$ in $\delta^{15} \mathrm{~N}$ between the maximum soya and the minimum casein values. The median $\delta^{15} \mathrm{~N}$ of casein $(5.49 \%$ ), being in good agreement with a previously reported value of $5.22 \%$ determined for casein from whole milk (Molkentin \& Giesemann, 2010), was markedly different compared with median values obtained for peanut $(1.20 \%$ ) and soya protein $(1.21 \%$ ). Hence, pure protein samples that originate from leguminous or bovine sources can easily be distinguished by $\delta^{15} \mathrm{~N}$. In the same way, casein containing elevated levels of leguminous protein should be distinguishable from genuine casein.

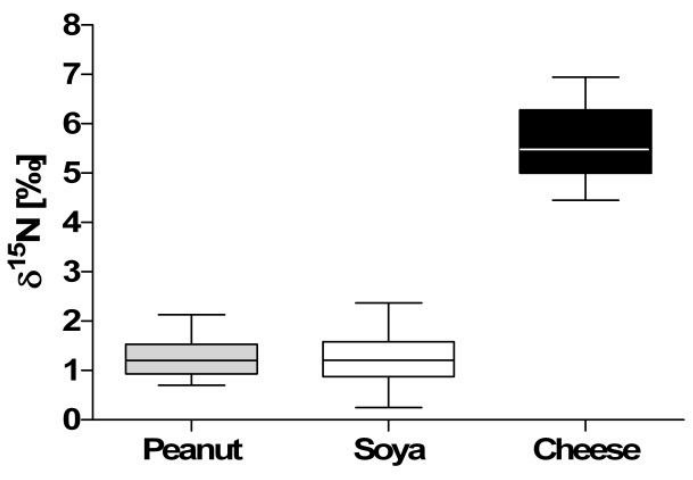

Figure 1. Variations (minimum, maximum, 25th and 75th percentile, median) of $\delta^{15} \mathrm{~N}$ in leguminous proteins and casein

With respect to recognizing the partial adulteration of milk products with vegetable proteins, it is important to determine the limit of detection (LOD), i.e. the maximum percentage of non-dairy protein not being detectable. If the composition of the pure components contained in a mixture is available for analysis, the LOD primarily depends on the precision of the analytical method $\left(L O D_{m t h}\right) . L O D_{m t h}$ can be calculated using the following equation (IUPAC, 2006), where $S D$ is the standard deviation of repeated analyses and $m$ is the slope of the regression line originating from data obtained from samples with an increasing percentage of leguminous protein (cf. Figure 2):

$$
L O D_{m t h}=3 \cdot S D / m
$$

Figure 2 shows an example of analysed $\delta^{15} \mathrm{~N}$ data obtained with mixtures (diamond symbols) containing soya protein $\left(\delta^{15} \mathrm{~N}=1.84 \%\right.$ o $)$ and casein $\left(\delta^{15} \mathrm{~N}=4.70 \%\right)$. The solid line indicates the theoretically expected results 
$\left(\delta^{15} \mathrm{~N}_{\text {exp }}\right)$, where $x$ is the mass fraction of leguminous protein:

$$
\delta^{15} N_{\text {exp }}=(1-x) \cdot \delta^{15} N_{\text {cas }}+x \cdot \delta^{15} N_{\text {leg }}
$$

The linear equation (Figure 2) was identical for the expected and analysed data and the experimental linearity was excellent $\left(\mathrm{R}^{2}=1.00\right)$. With a standard deviation of $0.03 \%$ for $\delta^{15} \mathrm{~N}$ determined in this study by repeated analyses of samples $(\mathrm{n}=5)$, a $L O D_{m t h}$ of $3.02 \%$ resulted for the mixtures shown in Figure 2, exemplarily.

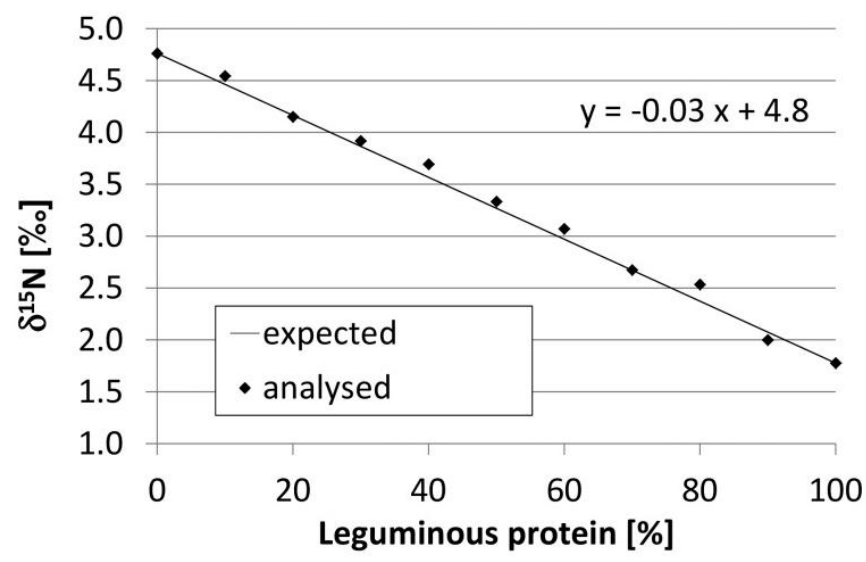

Figure $2 . \delta^{15} \mathrm{~N}$ in mixtures of soya protein with casein

Accordingly, the slope derived from expected $\delta^{15} \mathrm{~N}$ data was used to calculate $\mathrm{LOD}_{\mathrm{mth}}$ for mixtures $(10-90 \%$ leguminous protein) computed from different combinations of leguminous proteins and casein (Table 1). As can be seen from Equation 1, $L O D_{m t h}$ depends on the difference between $\delta^{15} \mathrm{~N}$ in casein and the leguminous protein. A higher difference increases the slope $m$ and consequently decreases the LOD. This can be seen in Table 1, which shows values of $L O D_{m t h}$ for combinations of leguminous proteins and casein with a minimum, median and maximum $\delta^{15} \mathrm{~N}$, respectively. The highest LODs for soya $(4.34 \%)$ and peanut $(3.88 \%)$ mixtures resulted from a minimum casein $\delta{ }^{15} \mathrm{~N}$ combined with a maximum leguminous protein $\delta^{15} \mathrm{~N}$, while reverse conditions led to LODs of $1.35 \%$ and $1.44 \%$, respectively. Based on median compositions, the $L O D_{m t h}$ of leguminous protein in casein using $\delta^{15} \mathrm{~N}$ analysis was $2.10 \%$.

Table 1. $L O D_{m t h}$ of leguminous protein in casein (\%) calculated from the method precision of $\delta^{15} \mathrm{~N}$ analysis

\begin{tabular}{lccc}
\hline & Soya $_{\min }$ & Soya $_{\text {med }}$ & Soya $_{\max }$ \\
\hline Casein $_{\min }$ & 2.14 & 2.78 & 4.34 \\
Casein $_{\text {med }}$ & 1.72 & 2.10 & 2.89 \\
Casein $_{\max }$ & 1.35 & 1.57 & 1.97 \\
\hline & Peanut $_{\text {min }}$ & Peanut $_{\text {med }}$ & Peanut $_{\max }$ \\
\hline Casein $_{\min }$ & 2.40 & 2.77 & 3.88 \\
Casein $_{\operatorname{med}}$ & 1.88 & 2.10 & 2.68 \\
Casein $_{\max }$ & 1.44 & 1.57 & 1.87 \\
\hline
\end{tabular}

Using $\delta^{15} \mathrm{~N}$ analysis, such small admixtures of leguminous protein of on average $2.1 \%$ in casein can only be detected, if the pure components of the composite protein samples were available for analysis. However, in the practice of food control, neither the added leguminous protein nor the casein, initially contained in the cheese-making milk, is available in case of a putative food adulteration. Consequently, the considerable variations of $\delta^{15} \mathrm{~N}$ in both potential components must be considered as a starting point. This makes the calculation of the LOD far more complex than determining a LOD just caused by analytical precision or sensitivity.

Depending on the actual $\delta^{15} \mathrm{~N}$ level in relation to the entire $\delta^{15} \mathrm{~N}$ variation of each protein component, different scenarios can be considered leading to a divergent LOD. Apriori, putative mixtures with a $\delta^{15} \mathrm{~N}$ within the whole variation range of casein must be considered as pure caseins in favour of the manufacturer. The addition of leguminous protein to casein can only be substantiated if $\delta^{15} \mathrm{~N}$ in a sample is below the lower limit of $\delta^{15} \mathrm{~N}$ variation in casein $\left(\operatorname{Cas}_{\min }\right)$. In order to achieve this condition, the actual $\delta^{15} \mathrm{~N}$ in casein $\left(\mathrm{Cas}_{a c t}\right)$ and leguminous 
protein $\left(\operatorname{Leg}_{\text {act }}\right)$ as well as their respective mass fraction must result in a composite $\delta^{15} \mathrm{~N}$ of the mixture below Cas $_{\text {min }}$, which represents the limit:

$$
\operatorname{Cas}_{\text {min }}=(1-x) \cdot \text { Cas }_{\text {act }}+x \cdot \operatorname{Leg}_{\text {act }}
$$

Under these practical conditions, without availability of pure components, the maximum LOD caused by the variation $\left(L O D_{v a r}\right)$ of $\delta^{15} \mathrm{~N}$ in casein $\left(C^{2} s_{\min }\right.$ to $\left.C a s_{\max }\right)$ occurs in a protein mixture with Cas $_{\max }$ but still depends on the actual $\delta^{15} \mathrm{~N}$ of the contained leguminous protein $\left(L e g_{a c t}\right)$. Solving Equation 3 for $x$, replacing $x$ by $L O D_{\text {var }}$ while converting from mass fraction to percent and substituting $\operatorname{Cas}_{a c t}$ by $\operatorname{Cas}_{\max }$ allows the determination of $L O D_{\text {var }}$ (max) for different levels of $\delta^{15} \mathrm{~N}$ in leguminous protein:

$$
L O D_{v a r}(\max )=\frac{\text { Cas }_{\max }-\text { Cas }_{\min }}{\text { Cas }_{\max }-\text { Leg }_{\text {act }}} \cdot 100
$$

As shown in Table 2, the $\mathrm{LOD}_{\text {var }}$ values for soya and peanut proteins were calculated for the minimum, median and maximum $\delta^{15} \mathrm{~N}$ of the respective leguminous protein. The worst case was the identification of a mixture containing leguminous protein with the highest possible $\delta^{15} \mathrm{~N}$, which resulted in non-detectable portions of over $50 \%$. Leguminous protein with a median composition can unambiguously be detected in percentages over $43.5 \%$, but even the lowest $\delta^{15} \mathrm{~N}$ still results in $L O D_{\text {var }}$ values of $37-40 \%$.

Table 2. $L O D_{\text {var }}(\%)$ of leguminous protein in casein with a maximum $\delta^{15} \mathrm{~N}$ and its dependence on $\delta^{15} \mathrm{~N}$ levels of leguminous protein

\begin{tabular}{lll}
\hline$\delta^{15} \mathrm{~N}$ & Soya & Peanut \\
\hline Max & 54.5 & 51.8 \\
Median & 43.5 & 43.4 \\
Min & 37.2 & 39.9 \\
\hline
\end{tabular}

The figures shown in Table 2 represent the worst case scenario with a maximum $\delta^{15} \mathrm{~N}$ for casein. However, the average $\delta^{15} \mathrm{~N}$ in casein was distinctly lower and by definition $50 \%$ of the pure casein samples showed a $\delta^{15} \mathrm{~N}$ lower than the median value (5.49\%). Taking the median $\delta^{15} \mathrm{~N}$ as a baseline, the median $L O D_{v a r}$ for leguminous protein can be calculated using the following equation:

$$
L O D_{\text {var }}(\text { med })=\frac{\text { Cas }_{\text {med }}-\text { Cas }_{\min }}{\text { Cas }_{\text {med }}-\text { Leg }_{\text {act }}} \cdot 100
$$

The figures resulting from Equation 5 are shown in Table 3 and represent the average LOD in the practice of food control. Consequently, $50 \%$ of composite protein samples will enable $L O D_{v a r}$ to be even lower. The lowest $L O D_{\text {var }}$ would be observed for mixtures of any leguminous protein and with casein having a minimum $\delta^{15} \mathrm{~N}$. In this case, $L O D_{v a r}$ would disappear and only $L O D_{m t h}$ would remain. On the other hand, $L O D_{\text {mth }}$ must generally be added to the figures of $L O D_{v a r}$ in Tables 2 and 3.

Table 3. $L O D_{\text {var }}(\%)$ of leguminous protein in casein with a median $\delta^{15} \mathrm{~N}$ and its dependence on $\delta^{15} \mathrm{~N}$ levels in leguminous protein

\begin{tabular}{lll}
\hline$\delta^{15} \mathrm{~N}$ & Soya & Peanut \\
\hline Max & 33.3 & 31.0 \\
Median & 24.3 & 24.2 \\
Min & 19.8 & 21.7 \\
\hline
\end{tabular}

Hence, composite samples containing leguminous protein and casein both having a median $\delta^{15} \mathrm{~N}$ showed an average $L O D_{\text {var }}$ of $24.25 \%$ (Table 3) and an $L O D_{m t h}$ of $2.10 \%$ (Table 1), resulting in a mean overall LOD of $26.35 \%$ for leguminous protein in casein. However, the LOD would be lower in 50\% of the composite samples.

Compared with electrophoretic (Cattaneo et al., 1994; Hewedy \& Smith, 1989; Kanning et al., 1993), immunologic (Haasnoot et al., 2001) or proteomic (Luykx et al., 2007) methods that all have LODs of $<1 \%$ for leguminous protein in casein, the LOD was considerably higher for stable isotope analyses of nitrogen when the pure components were not available. Also recent screening techniques (Cordewener et al., 2009; Jablonski et al., 2014; Scholl et al., 2014) allowed for a much more sensitive detection of about $1 \%$ plant protein. However, all these established methods require a more or less time consuming sample preparation and partly a long analysis 
time.

Alternatively, $\delta^{15} \mathrm{~N}$ determination can be used in applications where the presence of higher proportions of non-milk protein is the main focus. This is especially true for controls, where the focus is not on health, but on economic issues. Then, an IRMS-based screening method, which requires less effort than the other aforementioned techniques, can be used as a quick alternative. In particular, the detection of imitation cheese is a suitable application because such products usually do contain little or no casein. Moreover, as the vast majority of nitrogen is usually bound to the protein fraction of foods, a simple bulk analysis of crude food samples for $\delta^{15} \mathrm{~N}$ could be a straight forward option, i.e. the isolation of protein before analysis may not be required.

\section{Conclusion}

Due to the influence of atmospheric nitrogen, $\delta^{15} \mathrm{~N}$ in legumes such as soya and peanut is significantly lower than in casein. This allows the detection of leguminous protein admixtures in casein. If both protein components are available for analyses, the average LOD is approximately $2 \%$. Under practical conditions, examining putative composite samples isolated e.g. from cheese requires the consideration of potential variations within each component. Hence, these result in an average LOD of $26.4 \%$, which is considerably higher than values obtained using established methods. However, compared with electrophoretic, immunologic or proteomic procedures, the determination of $\delta^{15} \mathrm{~N}$ in milk products can be a rapid and simple alternative, especially with regard to potentially adulterated food items that would typically contain high amounts of leguminous protein. This approach would not be limited to cheese but probably can be extended to further protein containing milk products.

\section{Acknowledgment}

The author thanks Bärbel Krumbeck for her assistance in performing the analytical work for this study.

\section{References}

Camin, F., Bertoldi, D., Santato, A., Bontempo, L., Perini, M., Ziller, L., Stroppa, A., \& Larcher, R. (2015). Validation of methods for $\mathrm{H}, \mathrm{C}, \mathrm{N}$ and $\mathrm{S}$ stable isotopes and elemental analysis of cheese: results of an international collaborative study. Rapid Communications in Mass Spectrometry, 29, 415-423. https://doi.org/10.1002/rcm.7117

Cattaneo, T. M. P., Feroldi, A., Toppino, P. M., \& Olieman, C. (1994). Sample Preparation for Selective and Sensitive Detection of Soya Proteins in Dairy-Products with Chromatographic and Electrophoretic Techniques. Netherlands Milk and Dairy Journal, 48(4), 225-234.

Cordewener, J. H. G., Luykx, D. M. A. M., Frankhuizen, R., Bremer, M. G. E. G., Hooijerink, H., \& America, A. H. P. (2009). Untargeted LC-Q-TOF mass spectrometry method for the detection of adulterations in skimmed-milk powder. Journal of Separation Science, 32(8), 1216-1223. https://doi.org/10.1002/jssc.200800568

DeNiro, M. J., \& Epstein, S. (1981). Influence of diet on the distribution of nitrogen isotopes in animals. Geochim Cosmochim Acta, 45, 341-350. https://doi.org/10.1016/0016-7037(81)90244-1

EU, (2007). Council Regulation (EC) No 1234/2007 establishing a common organisation of agricultural markets and on specific provisions for certain agricultural products (Single CMO Regulation). Official Journal of the European Union, L299, 1-149.

Haasnoot, W., Olieman, K., Cazemier, G., \& Verheijen, R. (2001). Direct biosensor immunoassays for the detection of nonmilk proteins in milk powder. Journal of Agricultural and Food Chemistry, 49(11), 5201-5206. https://doi.org/10.1021/jf010440p

Hewedy, M. M., \& Smith, C. J. (1989). Detection of soy milk in pasteurized bovine milk. Food Hydrocolloids, 3(5), 399-405. https://doi.org/10.1016/S0268-005X(89)80014-1

IDF (2010). Milk and milk products - Determination of milk fat purity by gas chromatographic analysis of triglycerides (Reference method). International Standard ISO 17678|IDF 202. Brussels, Belgium: International Dairy Federation.

IUPAC (2006). Compendium of Chemical Terminology, 2nd ed. (the "Gold Book"). Compiled by A. D. McNaught and A. Wilkinson. Blackwell Scientific Publications, Oxford (1997). XML on-line corrected version: http://goldbook.iupac.org (2006-) created by M. Nic, J. Jirat, B. Kosata; updates compiled by A. Jenkins. ISBN 0-9678550-9-8. https://doi.org/10.1351/goldbook

Jablonski, J. E., Moore, J. C., \& Harnly, J. M. (2014). Nontargeted Detection of Adulteration of Skim Milk Powder with Foreign Proteins Using UHPLC-UV. Journal of Agricultural and Food Chemistry, 62(22), 
5198-5206. https://doi.org/10.1021/jf404924x

Jaiswal, P., Jha, S. N., Borah, A., Gautam, A., Grewal, M. K., \& Jindal, G. (2015). Detection and quantification of soymilk in cow-buffalo milk using Attenuated Total Reflectance Fourier Transform Infrared spectroscopy (ATR-FTIR). Food Chemistry, 168, 41-47. https://doi.org/10.1016/j.foodchem.2014.07.010

Luykx, D. M. A. M., Cordewener, J. H. G., Ferranti, P., Frankhuizen, R., Bremer, M. G. E. G., Hooijerink, H., \& America, A. H. P. (2007). Identification of plant proteins in adulterated skimmed milk powder by high-performance liquid chromatography-mass spectrometry. Journal of Chromatography A, 1164(1-2), 189-197. https://doi.org/10.1016/j.chroma.2007.07.017

Kanning, M., Casella, M., \& Olieman, C., (1993). Milk and soy proteins analysis using capillary zone electrophoresis. $L C$-GC Int,. 6, 701-705.

Minagawa, M., \& Wada, E. (1984). Stepwise enrichment of $15 \mathrm{~N}$ along food chains: further evidence and the relation between delta 15N and animal age. Geochim Cosmochim Acta, 48, 1135-1140. https://doi.org/10.1016/0016-7037(84)90204-7

Molkentin, J., \& Giesemann, A. (2007). Differentiation of organically and conventionally produced milk by stable isotope and fatty acid analysis. Analytical and Bioanalytical Chemistry, 388(1), 297-305. https://doi.org/10.1007/s00216-007-1222-2

Molkentin, J., \& Giesemann, A. (2010). Follow-up of stable isotope analysis of organic versus conventional milk. Analytical and Bioanalytical Chemistry, 398(3), 1493-1500. https://doi.org/10.1007/s00216-010-3995-y

Molkentin, J., Lehmann, I., Ostermeyer, U., \& Rehbein, H. (2015). Traceability of organic fish - Authenticating the production origin of salmonids by chemical and isotopic analyses. Food Control, 53, 55-66. https://doi.org/10.1016/j.foodcont.2015.01.003

Molkentin, J., \& Precht, D. (1998). Comparison of gas chromatographic methods for analysis of butyric acid in milk fat and fats containing milk fat. Zeitschrift Fur Lebensmittel-Untersuchung Und-Forschung a-Food Research and Technology, 206(3), 213-216. https://doi.org/10.1007/s002170050245

Scholl, P. F., Farris, S. M., \& Mossoba, M. M. (2014). Rapid Turbidimetric Detection of Milk Powder Adulteration with Plant Proteins. Journal of Agricultural and Food Chemistry, 62(7), 1498-1505. https://doi.org/10.1021/jf405617f

White, J. W., \& Winters, K. (1989). Honey Protein as Internal Standard for Stable Carbon Isotope Ratio Detection of Adulteration of Honey. Journal of the Association of Official Analytical Chemists, 72(6), 907-911.

Wu, R. G., Wang, Z. P., Fung, Y. S., Seah, D. Y. P., \& Yeung, W. S. B. (2014). Assessment of adulteration of soybean proteins in dairy products by 2D microchip-CE device. Electrophoresis, 35(11), 1728-1734. https://doi.org/10.1002/elps.201300559

\section{Copyrights}

Copyright for this article is retained by the author(s), with first publication rights granted to the journal.

This is an open-access article distributed under the terms and conditions of the Creative Commons Attribution license (http://creativecommons.org/licenses/by/4.0/). 